\title{
Erikoiskasveilla voidaan vaikuttaa peltomaan mikrobiston monimuotoisuuteen
}

\author{
Ansa Palojärvi ${ }^{1)}$, Saara Kaipainen ${ }^{1)}$, Sari Peura ${ }^{1)}$ ja Christian Eriksson ${ }^{2)}$ \\ ${ }^{1)}$ MTT (Maa- ja elintarviketalouden tutkimuskeskus),31600Jokioinen, ansa.palojarvi@mtt.fi \\ ${ }^{2)}$ MTT Tutkimuspalvelut,Tietopalvelut, 31600 Jokioinen
}

\section{Tiivistelmä}

Juuret ja maaperän mikrobit elävät kiinteässä vuorovaikutussuhteessa. Kasvilajien tiedetäänkin vaikuttavan maaperän mikrobiston määrään ja laatuun suosimalla eri mikrobeja juuristossaan. Maaperän mikrobeilla on suuri merkitys maaperän keskeisissä prosesseissa, kuten ravinteiden kierrossa ja kasvitautien luontaisessa torjunnassa. Viljeltyjen kasvilajien määrä on vähentynyt huomattavasti ja viljely on yksipuolistunut, mikä on johtanut eloperäisen aineksen ja monimuotoisuuden vähenemiseen viljelymaissa. Kasvattamalla maaperän mikrobi-monimuotoisuutta nostetaan samalla hyödyllisten mikrobien todennäköisyyttä esiintyä maaperässä. Vaikka maamikrobien ja kasvin juuriston välisiä yhteyksiä on tutkittu melko aktiivisesti, on tutkimukset useimmiten tehty tavallisimmilla viljelykasveilla. Tämän tutkimuksen tarkoituksena oli selvittää erikoiskasvien vaikutusta maaperän mikrobiyhteisöihin ja verrata erikoiskasvien vaikutusta kontrollikasvina toimineeseen ohraan. Tässä erikoiskasveilla tarkoitetaan kasveja, joita tällä hetkellä käytetään viljelykasveina melko vähän, mutta joilla on potentiaalia viljelykasveiksi.

Esityksessä kerrotaan tuloksia kahdesta astiakokeesta. 1. astiakoe toteutettiin kesällä 2003. Kokeessa oli mukana kaksi yleisesti viljeltyä kasvia, ohra (Hordeum vulgare) ja timotei (Phleum pratense) sekä yhdeksän erikoiskasvia. Erikoiskasvit olivat kumina (Carum carvi), ruokohelpi (Phalaris arundinaceae), värimorsinko (Isatis tinctoria), kinua (Chenopodium quinea), öljyhamppu (Cannabis sativa), kitupellava (Camelina sativa), pellava (Linum usitatissimum), tattari (Fagopyrum esculentum) ja nokkonen (Urtica dioica). Kasvit kylvettiin/istutettiin hienoa hietaa sisältäviin astioihin toukokuussa 2003. Astioita pidettiin lasikattoisessa astiakoehallissa, jossa on verkkoseinät. Näytteet yksivuotisista kasveista otettiin tuleentumisen aikaan ja monivuotisista kasveista elokuun lopussa. 2. astiakoe tehtiin kolmella eri maalla (savi, hietasavi, hieno hieta) kasvihuoneessa talvella 2004-05. Mukana olivat erikoiskasvit tattari ja kumina sekä kontrollikasvi ohra. Näytteet otettiin kukinnan aikaan (tattari, ohra) tai kuminalla ohran näytteenoton jälkeen. Jokaisesta ruukusta otettiin kaksi näytettä, löyhästi juuristoon sitoutuneesta maasta maanäyte ja juurten pinnalta ritsosfäärinäyte. Näytteistä analysoitiin mikrobibiomassa ja mikrobiyhteisön rakenne solukalvojen fosfolipidien rasvahappoanalyysin avulla.

Suurimmalla osalla kasveista mikrobibiomassa oli suurempi ritsosfäärissä kuin maassa, ja lisäksi mikrobibiomassa oli juuristossa suurempi suurimmalla osalla erikoiskasveista kuin kontrollikasvilla ohralla. Ainoastaan tattarilla ei ollut tilastollisesti merkitsevää eroa juuristo- ja maanäytteiden välillä ja tattarilla oli ohraan verrattuna pienempi mikrobibiomassa juuristonäytteissä. Mikrobiyhteisön rakenne oli erilainen juuristo- ja maanäytteissä, lisäksi kasvilajilla oli merkitystä juuristo- ja maanäytteiden erojen suuruuteen. Kuminalla, värimorsingolla, kinualla ja öljyhampulla oli suurimmat erot juuristo- ja maanäytteiden välillä ja ohraan verrattuna. Eri maissa oli toisistaan poikkeavat mikrobiyhteisöt, mutta ritsosfäärimikrobiston koostumukseen kasvilaji vaikutti maata enemmän.

Astiakokeiden tulosten perusteella voidaan olettaa, että tietyillä erikoiskasveilla voidaan muuttaa peltomaan mikrobiyhteisön suuruutta ja rakennetta. Viljelykasvien valinnalla voitaisiin siten ohjata maaperän mikrobiyhteisöä viljelyn kannalta suotuisaan suuntaan. 